https://nv.nltu.edu.ua

https://doi.org/10.36930/40310104

Article received 01.02.2021 p.

Article accepted 04.02.2021 p.

UDC 630.232.4

О. М. Даниленко ${ }^{1}$, В. С. Ющик ${ }^{2}$ М. Г. Румянцев ${ }^{2}$, А. А. Мостепанюк ${ }^{1}$

${ }^{1}$ ДП "Харківська лісова науково-дослідна станиіл", с. Черкаська Лозова, Украӥна

${ }^{2}$ Український ордена "Знак Помани" науково-дослідний інститут лісового господарства та агролісомеліораиії ім. Г. М. Висоиького, м. Харків, Україна

\title{
ОСОБЛИВОСТІ РОСТУ ТА СТАНУ СОСНОВИХ КУЛЬТУР, СТВОРЕНИХ РІЗНИМ САДИВНИМ МАТЕРІАЛОМ, У ПІВДЕННО-СХІДНОМУ ЛІСОСТЕПУ УКРАЇНИ
}

\begin{abstract}
Встановлено, що для умов Лівобережного Лісостепу України вкрай мало даних щодо особливостей росту лісових культур за участі сосни звичайної (Pinus sylvestris L.), створених різним садивним матеріалом, зокрема сіянцями із відкритою та закритою кореневими системами. Проте це питання на сьогодні є актуальним, оскільки вибір конкретного виду садивного матеріалу під час створення лісових культур має відповідний вплив на продуктивність майбутніх насаджень. Проведено порівняння показників росту лісових культур за участі сосни звичайної, створених сіянцями із відкритою та закритою кореневими системами, за п'ятирічний період їх вирощування в південно-східній частині Лівобережного Лісостепу України. Садіння дослідних культур проведено восени 2015 р. однорічними сіянцями сосни звичайної із закритою кореневою системою, вирощених в умовах відкритого грунту та навесні 2016 р. - однорічними сіянцями сосни звичайної із відкритою кореневою системою, вирощених в умовах закритого грунту. Схема розміщення садивних місць: для сіянців із відкритою кореневою системою $-2,5 \times 0,7$ м; для сіянців із закритою кореневою системою $-2,5 \times 1,0$ м. Під час досліджень використано загальноприйняті методики з лісівництва, лісознавства та лісових культур. Доведено, що біометричні показники саджанців (середні висота, діаметр і приріст за висотою) є достовірно більшими в соснових культурах, створених сіянцями із закритою кореневою системою, ніж відповідні їх значення у культурах, створених сіянцями із відкритою кореневою системою. У віці 5 років соснові культури, створені сіянцями із відкритою кореневою системою, характеризувалися такими показниками за ростом: висота - 166 см, діаметр на висоті 1,3 м - 33 мм, приріст за висотою - 44 см, а сіянцями із закритою кореневою системою 177, 38 і 46 см відповідно. Різниця у відносних значеннях становить $7 \%$ - за висотою, $15 \%$ - за діаметром на висоті 1,3 м, $4 \%$ - за приростом по висоті. Санітарний стан культур, створених сіянцями із закритою кореневою системою, $є$ дещо кращим, ніж культур, створених сіянцями із відкритою кореневою системою - I,2 проти I,3 відповідно. Окрім цього, лісові культури, створені сіянцями із закритою кореневою системою, у трирічному віці відзначалися розвиненішою кореневою системою (мали потужніші стрижневий і бічні корені) порівняно із культурами, створеними сіянцями із відкритою кореневою системою. Ці особливості загалом сприяли кращій приживлюваності й успішнішому подальшому росту створених лісових культур. Результати проведених досліджень доцільно враховувати під час розроблення нових або вдосконалення чинних нормативних актів із ведення лісового господарства в соснових лісах.
\end{abstract}

Ключові слова: лісовідновлення; сіянці із відкритою кореневою системою; сіянці із закритою кореневою системою; індекс санітарного стану; біометричні показники.

\section{Вступ}

Серед способів відтворення лісів (природного, штучного або комбінованого) продовжує переважати штучний (створення лісових культур). У сучасній структурі лісового фонду Лівобережного Лісостепу частка соснових насаджень штучного походження становить близько $95 \%$ від загальної площі соснових лісів. Така тенденція зберігатиметься й надалі, що пов'язано із особливостями ведення лісового господарства в соснових лісах регіону. Через 20-40 років, за розрахунками на- уковців, існує тенденція до різкого збільшення площ, що потребуватимуть лісовідновлення, оскільки досягнуть віку стиглості насадження, які були створені в післявоєнний час на великих площах, зокрема і в межах Лівобережного Лісостепу.

Збільшення обсягів робіт із відтворення лісів у майбутньому потребуватиме інтенсивного розвитку новітніх технологій з вирощування садивного матеріалу, які забезпечили б ефективне створення та вирощування якісних лісових культур різного цільового призначення. Це передбачатиме ширше використання садивного ма-

\section{Інформація про авторів:}

Даниленко Олег Миколайович, мол. наук. співробітник. Email: dandik86@gmail.com

Ющик Віта Сергіївна, мол. наук. співробітник, лабораторія лісових культур та агролісомеліорації. Email: vitay2715@gmail.com

Румянцев Максим Григорович, канд. с.-г. наук, ст. наук. співробітник, лабораторія лісових культур та агролісомеліорації. Email: maxrum-89@ukr.net; https://orcid.org/0000-0002-2245-2441

Мостепанюк Андрій Андрійович, директор. Email: xlnds15@ukr.net

Цитування за ДСтУ: Даниленко О. М., Ющик В. С., Румянцев М. Г., Мостепанюк А. А. Особливості росту та стану соснових культур, створених різним садивним матеріалом, у Південно-східному лісостепу України. Науковий вісник Нлту України. 2021, т. 31, № 1. С. 26-29.

Citation APA: Danylenko, O. M., Yushchyk, V. S., Rumiantsev, M. N., \& Mostepaniuk, A. A. (2021). Some features of the growth and condition of pine plantations created by different planting material in the South-eastern Forest-steppe of Ukraine. Scientific Bulletin of UNFU, 31(1), 26-29. https://doi.org/10.36930/40310104 
теріалу із закритою кореневою системою (ЗКС) під час лісовідновлення та лісорозведення.

Вирощування садивного матеріалу із ЗКС, порівняно $з$ відкритою кореневою системою (ВКС), має низку переваг та дає змогу: економно вносити під кожний сіянець добрива, регулятори росту рослин та інші цільові речовини і препарати; ефективно використовувати покращене насіння; цілеспрямовано управляти ростом сіянців для оптимізації співвідношення надземної та підземної їх частини; отримувати впродовж одного вегетаційного періоду 2-3 ротації високоякісного садивного матеріалу; продовжити період садіння лісових культур під час усього вегетаційного періоду; садити культури великомірним садивним матеріалом із максимальною збереженістю кореневої системи; знизити витрати на доповнення лісових культур через високу приживлюваність садивного матеріалу; загалом підвищити ефективність створення лісових культур $[1,2,3,6,10,12]$.

Нині, коли спостерігається зростання посушливості клімату, особливої уваги заслуговує технологія вирощування сіянців із ЗКС. Разом із цим, питання впливу режиму вирощування садивного матеріалу лісових порід на стан і подальший ріст сіянців у лісових культуpax ще вивчені недостатньо. Зазвичай дослідження ефективності використання садивного матеріалу із ЗКС обмежувалися одним-двома роками після садіння на лісокультурну площу.

Об'єкт дослідження - лісові культури за участю сосни звичайної (Pinus sylvestris L.) віком 5 років, створені сіянцями із відкритою (0,6 га) та закритою кореневими системами (1,8 га), у Липецькому лісництві (кв. 125, вид. 26) державного підприємства "Харківська лісова науково-дослідна станція" (ДП "Харківська ЛНДС") Українського науково-дослідного інституту лісового господарства та агролісомеліорації імені Г. М. Висоцького (УкрНДІЛГА).

Предмет дослідження - приживлюваність, особливості росту та санітарний стан досліджуваних лісових культур за участі сосни звичайної.

Мета роботи - визначити приживлюваність лісових культур за участі сосни звичайної, їх біометричні показники (середні висота, діаметр і приріст за висотою) i санітарний стан.

Для досягнення зазначеної мети визначено такі ocновні завдання дослідження: щорічне визначення приживлюваності та біометричних показників (середні висота, діаметр і приріст за висотою саджанців) способом ïx безпосереднього вимірювання із наступною фіксацією у польових картках обліку дослідів.

Наукова новизна отриманих результатів дослідження - вперше для умов південно-східної частини Лівобережного Лісостепу отримано дані біометричних показників (середні висота, діаметр і приріст за висотою) саджанців сосни віком 5 років, створені сіянцями із закритою кореневою системою, та проведено їх порівняння із показниками саджанців сосни такого самого віку, створені сіянцями із відкритою кореневою системою.

Практична значущиість результатів дослідження результати здійснених досліджень в подальшому будуть використані під час розроблення вихідного документу "Рекомендації щодо удосконалення технології вирощування лісових культур із використанням садивного матеріалу із закритою кореневою системою (2024 р.)" за темою бюджетною темою № 11 "Дослідити ріст і розвиток лісових культур, створених садивним матеріалом із закритою кореневою системою, та розробити рекомендації щодо удосконалення технології їх створення" (№ держреєстрації: 0120U101897), замовником якої є Державне агентство лісових ресурсів України, пророблюваної в лабораторії лісових культур та агролісомеліорації УкрНДІЛГА.

Аналіз останніх досліджень та публікацій. Соснові насадження Лівобережного Лісостепу є менш вивченими порівняно із дубовими. У деяких наукових працях $[4,7,9,11]$ охарактеризовано сучасний стан, вікову структуру, типологічне різноманіття та продуктивність соснових насаджень, досліджено вплив господарських заходів (доглядових рубань різної інтенсивності та способів) на їх ріст, вивчено особливості формування в них підросту, живого надгрунтового покриву тощо. Проте немає даних щодо особливостей росту лісових культур за участі сосни звичайної, створених різним видом садивного матеріалу, зокрема сіянцями із відкритою та закритою кореневими системами. Тому це питання нині актуальне, оскільки вибір конкретного виду садивного матеріалу під час створення лісових культур, має відповідний вплив на продуктивність майбутніх насаджень.

Матеріали та методи дослідження. Садивний матеріал сосни звичайної вирощено в 2015 р. на селекційно-насінницькому комплексі Південного лісництва ДП "Харківська ЛНДС" $з$ попередньо підготовленого покращеного насіння: сіянці із ВКС - за загальноприйнятою технологією в закритому грунті, сіянці із ЗКС - в умовах відкритого грунту в індивідуальних контейнеpax iз агроволокна. Розміри контейнерів: висота$25 \mathrm{~cm}$, діаметр $-6 \mathrm{cм}$, об'єм - $707 \mathrm{~cm}^{3}$. Склад субстрату для заповнення контейнерів - суміш добрегумусованого темно-сірого середньосуглинкового та супіщаного грунтів у співвідношенні 1:1, торф перехідного типу та перегній-сипець у співвідношенні за об'ємом - 3:1:0,25. Садіння культур здійснювали вручну: сіянці із ЗКС під мотобур, а сіянці із ВКС - під меч Колесова. Обробіток грунту полягав у прокладанні плугом комбінованим лісовим (ПКЛ-70) плужних борозен завширшки $60 \mathrm{~cm}$

Для дослідження особливостей росту лісових культур сосни звичайної, створених сіянцями із ВКС та ЗКС, у ДП "Харківська ЛНДС", що територіально розміщене в південно-східній частині Лівобережного Лісостепу, впродовж 2012-2019 рр. було закладено п'ять науково-дослідних об'єктів на площі 9,2 га, на яких досліджуватимуться вплив різних способів інтенсифікації під час вирощування сіянців сосни із ЗКС в індивідуальних контейнерах із агроволокна в умовах закритого i відкритого грунту на приживлюваність і подальший їхній ріст у культурах, можливість літнього садіння сіянців із ЗКС та проводитиметься порівняння показників росту із сіянцями з ВКС.

Один із таких об'єктів створено в Липецькому лісництві (кв. 125, вид. 26). Категорія лісокультурної площі - свіжий зруб. Тип лісу - свіжий дубово-сосновий субір $\left(B_{2}-\partial C\right)$. Садіння культур проведено восени 2015 р. на площі 1,8 га сіянцями сосни звичайної із ЗКС, вирощених в умовах відкритого грунту та навесні 2016 р. на площі 0,6 га-сіянцями сосни звичайної із ВКС, вирощених в умовах закритого грунту. Схема роз- 
міщення садивних місць: для сіянців із $\mathrm{BKC}$ $2,5 \times 0,7 \mathrm{м}$; для сіянців із $3 К \mathrm{C}-2,5 \times 1,0 \mathrm{M}$.

Приживлюваність одно-трирічних культур сосни оцінювали в кінці вегетаційного періоду як співвідношення кількості живих саджанців на момент обліку та висаджених під час закладання досліду, виражене у відсотках. Біометричні показники культур сосни (середні висота, діаметр і приріст за висотою) визначали щорічно впродовж п'яти років прямим вимірюванням із наступною фіксацією у польових картках обліку дослідів. Щорічно обстеженню підлягали не менше 200 рослин кожного із варіантів (із ВКС і ЗКС).

Санітарний стан досліджуваних культур оцінювали візуально із врахуванням пошкодження гілок, стовбурів, коріння (загалом та їх частин), зміни форми крон. Кожному виду пошкодження встановлювали кодовий номер [8]. Ступінь пошкодження лісових культур, який характеризується індексом стану (Ic), розраховували за такою формулою:

$$
\text { Ic }=\frac{1}{N} \sum_{j=1}^{N} K_{j} \cdot n_{j},
$$

де: $I c$ - індекс стану деревостану; $K_{j}-j$-та категорія стану дерев (від I до VI); $n_{j}$ - кількість саджанців сосни $j$-ої категорії стану, шт.; $N$ - загальна кількість досліджених саджанців сосни, шт.

Статистичне оброблення результатів досліджень виконано засобами пакету програм MS Excel за [5].

\section{Результати дослідження та їх обговорення}

Результати проведених досліджень у кінці першого вегетаційного періоду після створення лісових культур свідчать, що значно кращою приживлюваністю характеризувалися культури, створені сіянцями із ЗКС (96\%), ніж культури, створені сіянцями із ВКС (80\%). Значний відпад рослин (із ВКС) пов'язаний із пошкодженням їхньої кореневої системи хрущами через можливе садіння у весняний період.

На вересень 2016 р. (вік культур - 1 рік) лісові культури, створені сіянцями із ВКС, характеризувалися такими показниками за ростом: висота $-15 \mathrm{~cm}$, діаметр кореневої шийки - 7 мм, приріст за висотою -7 см, а сіянцями із ЗКС - 23, 9 і 10 см відповідно (таблиця).

Таблиця. Середні біометричні показники саджанців сосни звичайної в культурах, створених сіянцями із ВКС та ЗКС, за роками обліків

\begin{tabular}{|c|c|c|c|c|c|c|c|c|c|}
\hline \multirow{2}{*}{ Варіант досліду } & \multicolumn{3}{|c|}{ Висота, см } & \multicolumn{3}{|c|}{ Приріст за висотою, см } & \multicolumn{3}{|c|}{ Діаметр, мм } \\
\hline & $M \pm m$ & $T f$ & $\%$ & $M \pm m$ & $T f$ & $\%$ & $M \pm m$ & $T f$ & $\%$ \\
\hline \multicolumn{10}{|c|}{ Станом на 2016 р. (вік культур - 1 рік) } \\
\hline Лісові культури, створені сіянцями з ВКС & $15,1^{ \pm 1,37}$ & - & 100 & $7,3^{ \pm 0,98}$ & - & 100 & $6,8^{ \pm 0,27}$ & - & 100 \\
\hline Лісові культури, створені сіянцями з ЗКС & $22,7^{ \pm 1,12}$ & 4,29 & 150 & $10,1^{ \pm 0,85}$ & 2,15 & 138 & $8,5^{ \pm 0,35}$ & 3,80 & 125 \\
\hline \multicolumn{10}{|c|}{ Станом на 2018 р. (вік культур - 3 роки) } \\
\hline Лісові культури, створені сіянцями з ВКС & $60,6^{ \pm 1,55}$ & - & 100 & $27,5^{ \pm 0,90}$ & - & 100 & $12,6^{ \pm 0,35}$ & - & 100 \\
\hline Лісові культури, створені сіянцями з ЗКС & $77,8^{ \pm 1,65}$ & 7,60 & 128 & $33,2^{ \pm 0,83}$ & 4,63 & 121 & $14,6^{ \pm 0,31}$ & 4,23 & 116 \\
\hline \multicolumn{10}{|c|}{ Станом на 2020 р. (вік культур - 5 років) } \\
\hline Лісові культури, створені сіянцями з ВКС & $165,6^{ \pm 3,59}$ & - & 100 & $43,8^{ \pm 1,71}$ & - & 100 & $33^{ \pm 0,1}$ & - & 100 \\
\hline Лісові культури, створені сіянцями з ЗКС & $177,1^{ \pm 4,64}$ & 1,96 & 107 & $45,6^{ \pm 2,32}$ & 0,62 & 104 & $38^{ \pm 0,12}$ & 3,20 & 115 \\
\hline
\end{tabular}

Примітка: $M \pm m$ - середнє значення вимірюваного показника та його стандартне відхилення; $T f-t$-критерій Ст'юдента, \% (перевищення вимірюваного показника порівняно з контролем у відсотках) $\left(T f_{0.01}=2,63, T f_{0.05}=1,98\right)$.

Отримані дані статистично підтверджують переважання середніх біометричних показників рослин у культурах, створених сіянцями із ЗКС, порівняно із культурами, створених сіянцями із ВКС, - за висотою на $50 \%$, діаметром кореневої шийки - на $25 \%$, приростом за висотою - на $38 \%$.

На вересень 2018 р. (вік культур - 3 роки) лісові культури, створені сіянцями із ВКС, характеризувалися такими показниками за ростом: висота -61 см, діаметр кореневої шийки - 13 мм, приріст за висотою - 27 см, а сіянцями із ЗКС - 78 см, 15 мм і 33 см відповідно.

Отримані дані статистично підтверджують переважання середніх біометричних показників рослин у культурах, створених сіянцями із ЗКС, порівняно 3 культурами, створених сіянцями із ВКС, - за висотою на $28 \%$, діаметром кореневої шийки - на $16 \%$, приростом за висотою - на $21 \%$. Відзначимо також кращу збережуваність та санітарний стан культур, створених сіянцями із ЗКС - 92 проти 76 \% та I,2 проти I,4 відповідно.

Загалом завдяки кращій приживлюваності, а також часу створення культур (осінній період попереднього року) відзначено успішний подальший ріст лісових культур, створених сіянцями із ЗКС (рисунок).

Станом на вересень 2020 р. (вік культур - 5 років) лісові культури, створені сіянцями із ВКС, характеризувалися такими показниками за ростом: висота - $166 \mathrm{~cm}$, діаметр на висоті 1,3 м - 33 мм, приріст за висотою $44 \mathrm{~cm}$, а сіянцями із ЗКС - $177 \mathrm{~cm}, 38 \mathrm{мм}$ і $46 \mathrm{~cm}$ відповідно (див. таблицю).

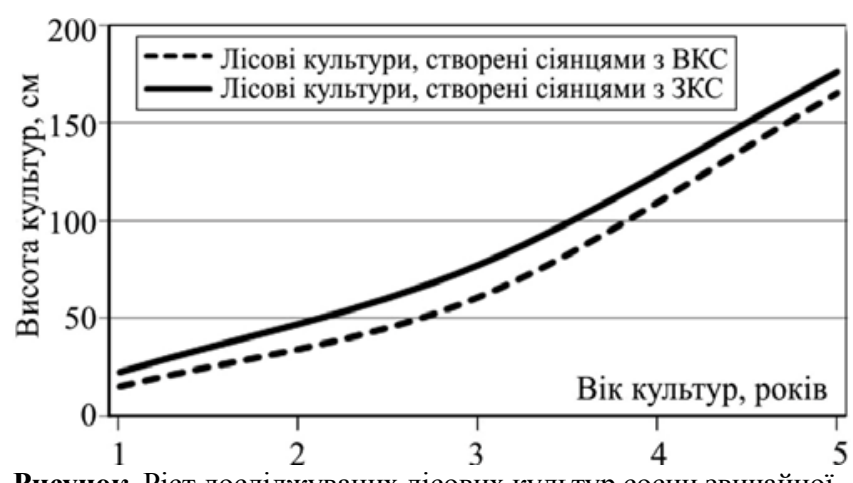

Рисунок. Ріст досліджуваних лісових культур сосни звичайної, створених сіянцями із ВКС та ЗКС, за висотою

Результати здійснених досліджень також свідчать про переважання середніх біометричних показників культур, створених сіянцями із ЗКС, порівняно з культурами, створених сіянцями із ВКС. Проте ця різниця вже $\epsilon$ не такою істотною як у трирічному віці: за висотою на $7 \%$, діаметром на висоті 1,3 м - на $15 \%$, приростом за висотою - на $4 \%$. Санітарний стан культур, створених сіянцями із ЗКС, є дещо кращим, ніж культур, створених сіянцями із ВКС - I,2 проти I,3 відповідно. 


\section{Висновки}

Результати проведених досліджень лісових культур, створених сіянцями із ВКС та ЗКС в умовах свіжого дубово-соснового субору, свідчать, що застосування під час вирощування сіянців із ЗКС в індивідуальних контейнерах способів інтенсифікації для їх росту сприяє кращій приживлюваності сіянців на лісокультурній площі в перший рік, збережуваності лісових культур у трирічному віці, переважанні середніх біометричних показників (висоти, діаметра та приросту за висотою) та кращому санітарному стану в п'ятирічному віці порівняно із сіянцями із ВКС, вирощених в умовах закритого грунту.

Результати проведених досліджень доцільно враховувати під час розроблення нових або вдосконалення чинних нормативних актів із ведення лісового господарства в соснових лісах, зокрема "Рекомендацій щодо удосконалення технології вирощування лісових культур із використанням садивного матеріалу із закритою кореневою системою" в питаннях виду садивного матеріалу, строків садіння лісових культур і схеми розміщення садивних місць.

\section{References}

1. Andreeva, O. Yu., Huzii, A. I., \& Karchevskyi, R. A. (2016). Some parameters of pine growth in plantations created with potted planting material. Scientific Bulletin of UNFU, 26(3), 9-14. https://doi.org/10.15421/40260301

2. Borisova, V. V. (2008). Influence of sprout treatment with preparation "Athlete" on development of Pinus sylvestris L. seedlings and their further growth in plantations. Forestry and Forest Melioration, 112, 159-164.

3. Brodovich, R. I., Katsulyak, Yu. D., \& Brodovich, Yu. R. (2001). Experience of cultivation and efficiency of coniferous seedlings with the closed rooted system use. Forestry and Forest Melioration, 100, 81-86.

4. Garmash, A. V. (2019). Pine stands of Forest-Steppe zone of Kharkiv Region: productivity and natural regeneration. Forestry and Forest Melioration, 125, 14-23. https://doi.org/10.33220/1026-3365.135.2019.14

5. Lakin, G. F. (1990). Biometrics: Study Guide. Moscow: Vysshaya shkola, 352 p. [In Russian].

6. Lyalin, O. I. (2008). Condition and growth of pine plantations created with containerized planting material. Forestry and Forest Melioration, 113, 93-100.

7. Mihaylichenko, O. A., \& Ustsky, I. M. (2016). Dynamics of age structure and health status of pine stands created on old arable lands in the Kharkiv hillslope region during 2001-2011. Forestry and Forest Melioration, 128, 143-147.

8. Resolution of Cabinet of Ministers of Ukraine. No 756 dated 26.10.2016. "Sanitary Forests Regulations in Ukraine". (Accessed on 28 January 2021). Retrieved from: http://zakon2.rada.gov.ua/laws/show/555-95-p

9. Tarnopilska, O. M., \& Ponomarev, O. A. (2008). Influence of selective and linear \& selective thinning on forming of pine plantations in the South Forest Steppe. Forestry and Forest Melioration, $113,111-120$.

10. Vedmid, M. M., \& Demchenko, O. G. (2004). Survival and growth of Pinus silvestris L. Plantations at seedling roots treatment before planting by growth regulators. Scientific Bulletin of UNFU, 14(8), 421-425. Retrieved from: https://nv.nltu.edu.ua/Archive/2004/14_8/84.pdf. [In Ukrainian].

11. Yarotsky, V. Yu., Pyvovar, T. S., Pasternak, V. P., \& Garmash, A. V. (2016). The structure of pine stands at the Left-bank Forest-steppe of Ukraine. Scientific Bulletin of UNFU, 26(4), 5659. https://doi.org/10.15421/40260408

12. Yashchuk, I. V., \& Shlonchak, G. A. (2019). Experience incultivating Scots pine seedlings using plant growth regulators in the Klavdiyevske Forestry Enterprise. Forestry and Forest Melioration, 134, 43-46. https://doi.org/10.33220/1026-3365.134.2019.43

O. M. Danylenko', V. S. Yushchyk', M. N. Rumiantsev' ${ }^{2}$, A. A. Mostepaniuk ${ }^{1}$

${ }^{1}$ SE "Kharkivska Forest Research Station", Cherkaska Lozova, Ukraine ${ }^{2}$ Ukrainian Research Institute of Forestry and Forest Melioration named after G. M. Vysotsky, Kharkiv, Ukraine

\section{SOME FEATURES OF THE GROWTH AND CONDITION OF PINE PLANTATIONS CREATED BY DIFFERENT PLANTING MATERIAL IN THE SOUTH-EASTERN FOREST-STEPPE OF UKRAINE}

Afforestation, which is artificial creation of forest plantation, continues to dominate among the methods of forest regeneration such as natural, artificial, and combined. This trend will continue due to the features of forest management in pine forests. This will involve greater use of planting material with a closed root system during the regeneration of pine forests. The results of the research have revealed that there are almost no data on the features of the pine plantations growth with the participation of Scots pine (Pinus sylvestris L.), created by different types of planting material, including seedlings with open root system and closed root system for the conditions of the Left-bank Forest-steppe of Ukraine. The research used generally accepted methods of forestry, forest sciences and forest plantation. The comparison of forest crop growth rates with the participation of Scots pine created by seedlings with open and closed root systems, over a five-year period of their cultivation in the south-eastern part of the Left-bank Forest-steppe of Ukraine. The biometric indicators of seedlings such as average height, diameter, and height increase are proved to be significantly higher in pine plantations created by seedlings with a closed root system than their corresponding values of crops created by seedlings with an open root system. At 5-year age pine plantations, created with seedlings with an open root system were characterized by the following indicators of growth: height $-166 \mathrm{~cm}$, diameter at a height of $1.3 \mathrm{~m}-33 \mathrm{~mm}$, growth in height $-44 \mathrm{~cm}$, and seedlings with a closed root system $-177 \mathrm{~cm}, 38 \mathrm{~mm}$ and $46 \mathrm{~cm}$ accordingly. The difference in relative values is $7 \%$ in height, $15 \%$ in diameter at a height of $1.3 \mathrm{~m}, 4 \%$ in height. The sanitary condition of plantations created using seedlings with a closed root system is slightly better than crops created by seedlings with an open root system, i.e. I.2 against I.3, respectively. In addition, forest plantations created by seedlings with a closed root system, at the age of three, had a more developed root system (had stronger taproot and lateral roots) compared to crops created by seedlings with an open root system. These features contributed to better survival and more successful further growth of forest plantations. The results of the research should be taken into account when developing new or improving existing regulations on forest management in pine forests. cators.

Keywords: reforestation; seedlings with an open root system; seedlings with a closed root system; sanitary index; biometric indi- 